\title{
Annex
}

\section{First Latin American's academies of pharmacy meeting declaration}

\author{
Valparaiso - Chile \\ 7-9 April 2005
}

Academies, as privileged institutions of scientific excellence, must exercise an undisputed leadership and give character and profile to the pharmaceutical sciences. The stability of its composition, the independence of its recruitment, freedom of their judgments and economic disinterest that preside over its proceedings are, among other, characteristics that distinguish them within the world of knowledge organizations. They are also responsible for promoting transnational cooperation, through programs aimed at the pursuit of quality, as recognized by UNESCO in its World Declaration on higher education in the $21^{\text {st }}$ century.

Globalization must today constitute an essential foundation to focus on academic policy. This trend towards convergence between Academies, is indispensable for the pharmaceutical development, given the clear complementarities of institutions.

Consequently, gathered in Valparaiso, on 7, 8 and 9 April of this year, the different iberolatinoamerican academies, following the conclusion of its first international meeting, have found it necessary to highlight the level of the scientific contributions made by the various participants of the same; with special emphasis on issues relating to globalization, efficacy, safety and accessibility of drugs, as well as to the educational aspects of harmonization, scientific-technological, legislative, deontological and ethical affecting, among others, professional secrecy and scientific objection of the pharmacist, as last of the missions that the company responsible for it is assigned in the field of health.

After exposure in the specific session of academies, agreed, among others, to continue with this type of meetings, to which media and activities necessary in order to fulfill the above purposes will be enabled. Thus, it seems advisable to establish a basis biannual for this type of meetings, therefore intends to set up a permanent Commission to comply with the foregoing, as well as set the strategies and guidelines for such purposes.

It is therefore agreed to create the International Association of Academies of Pharmacy (AIAF), having as philosophy of operation, continue spreading in the future commitments of all pharmaceutical sector that will combine specific knowledge history, statutory rigor, independence of judgement, and diversity specialists-with the scientific, technical and humanistic values of the pharmaceutical sciences. 
Therefore acquired the commitment to disseminate this statement of Valparaiso, all those responsible for health, educational and cultural policy in order to be taken into consideration in the decision-making, at the national and international levels.

IBEROLATINOAMERICAN ACADEMIES PRESENT AT THE FIRST MEETING (PEIAF)

- ROYAL NATIONAL ACADEMY OF PHARMACY OF SPAIN

- PHARMACY IBERO-AMERICAN OF ACADEMY

- ROYAL ACADEMY OF PHARMACY OF CATALONIA

- ACADEMY OF PHARMACY OF GALICIA

- ACADEMY OF PHARMACY SANTA MARÍA OF SPAIN FORM MURCIA REGION

- NATIONAL ARGENTINEAN ACADEMY OF PHARMACY AND BIOCHEMISTRY

- NATIONAL ACADEMY OF PHARMACY OF BRAZIL

- ACADEMY OF PHARMACEUTICAL SCIENCES OF MEXICO

- ACADEMY OF SCIENCES PHARMACEUTICAL OF CHILE

Editorial Committee: Aquiles Arancibia, Benito del Castillo, Pedro Martínez, Regina Pezoa, Alberto Ramos-Cormenzana y Claudio Sanahuja. 